\title{
Chapter 3. The Prehistory of Oceanic Languages: A Current View
}

\section{Andrew Pawley and Malcolm Ross}

The paper sketches the linguistic comparative method and reports on current results of its application to the Oceanic group of Austronesian languages. We give a brief account of the culture of Proto-Oceanic speakers as it is revealed by language, then outline our present view of Oceanic subgrouping, explaining what this implies about the location of Proto-Oceanic and the dispersion of Oceanic speakers into the Pacific. We examine patterns discernible in this dispersion, and address the question of why the languages of Melanesia have changed more than others.

\section{Introduction}

\section{Some questions}

Proto-Oceanic (POc) is the ancestor of some 450 Austronesian languages of Melanesia, Micronesia and Polynesia. Darrell Tryon has outlined in his paper for this volume the origins and position of the Oceanic subgroup within the wider Austronesian language family. Our concern here is with what historical linguistics has to say about the development of the Oceanic languages and the cultures of their speakers from Proto-Oceanic times onward. ${ }^{l}$

We will address the following questions:

1. How solid is the integrity of the Oceanic subgroup?

2. What was the culture of Proto-Oceanic speakers like?

3. What was the order of genetic splits among the languages of the Oceanic subgroup?

4. Where were Proto-Oceanic and later interstage languages spoken?

5. How did Proto-Oceanic and later interstage languages break up? Is a recurrent pattern discernible?

6. Why have some Oceanic languages of Melanesia changed much more than others?

7. How and why did Proto-Oceanic culture change in the daughter communities?

First, however, a few remarks on the methods of historical linguistics are in order. 


\section{The Comparative Method}

The historical linguist's main tool is the Comparative Method. ${ }^{2}$ It needs to be stressed that, in spite of its name, this method is completely different from the comparative method used in ethnological reconstruction, which is based on typological similarities.

The linguistic Comparative Method gains its strength from four facts associated with the sound systems of language or with the relation between sounds and meanings. Firstly, each word or morpheme in a language consists of a sequence of sounds which themselves have no meaning. Secondly, the association of meanings with sound sequences in a particular language is in almost all cases arbitrary. Thirdly, sound changes occur in all languages over time and, fourthly, these changes are, typically, regular. Regularity of sound change means that within a language community pronunciations change systematically, such that sound $x$ becomes sound $y$ under statable phonological conditions not just in a few words but in all words that meet those conditions. Together, these facts allow us to identify genetically related languages and to recognize genetically related morphemes or cognates shared by sister languages, as opposed to borrowed morphemes and accidental resemblances.

The comparative linguist takes sets of words and looks for regular sound correspondences among them. For example, among the cognate sets from widely distributed Oceanic languages in Table 1, we see a sound correspondence recurring in medial position in the words for 'paddle', 'rain' and 'name' between Manam - $r_{-}$, Takia - $\varnothing_{-}$, Mangap - $z_{-}$, Motu - $d_{-}$, Mekeo - $k_{-}$, Bali-Vitu - $z_{-}$, Tolai - $\varnothing_{-}$, Nyindrou - $r-$, Gela $-h_{-}$, Lau $-t-$, Bauan - -, and Tongan $-h-$. In these and later comparisons, $\varnothing$ indicates zero, i.e. loss of a sound present at an earlier stage.

Another correspondence set is reflected by initial $v$ - in the Gela items for 'full', 'turtle', and 'paddle'. We find Manam $\emptyset_{-}$, Takia $f_{-}$, Mangap $p_{-}$, Motu $h_{-}$, Mekeo $p^{-}$, Bali-Vitu $v_{-}$, Nyindrou $b_{-}$, Gela $v_{-}$, Lau $f_{-}$, Bauan $v_{\text {- }}$ and Tongan $f_{-}$. Notice, however, that initial $v$-also occurs in the Gela items for 'woman' and 'stone', but here the Takia correspondence is $p^{-}$, not $f$-. This is the result of phonological conditioning: Takia has $f$ - before what was once $-o^{-}$, and $p$ - before $-a$-. Similarly, medial $-v$ - in Gela vaivine 'woman' corresponds with Takia - $\emptyset$ - in pein, since POc * $p$ is lost between vowels in Takia.

Where sound correspondences like those exemplified in Table 1 recur throughout the vocabularies of the languages concerned, we know that the languages are genetically related to one another. That is, we can demonstrate that the related words are formally derived in a regular manner from a common ancestral language. 
Table 1. Some Oceanic cognate sets. ${ }^{(a)}$

\begin{tabular}{|c|c|c|c|c|c|c|c|}
\hline & 'full' & 'turtle' & 'paddle' & 'woman' & 'rain' & 'stone' & 'name' \\
\hline POc & ${ }^{*}$ ponuq & ${ }^{*}$ poñu & ${ }^{*}$ pose & ${ }^{*}$ papine ${ }^{(\mathrm{b})}$ & ${ }^{*}$ qusan & ${ }^{*}$ patu & ${ }^{*}$ qasan $^{\text {1c }}$ \\
\hline \multicolumn{8}{|c|}{ Papua New Guinea north coast } \\
\hline Manam & uni & $\ldots$ & ore & aine & ura & $\ldots$ & ara- \\
\hline Takia & $\ldots$ & fon & $f e i$ & pein & $u i$ & pat & $\ldots$ \\
\hline Mangap & pin & pen & peze & (waine) & $\ldots$ & pat & za- \\
\hline \multicolumn{8}{|c|}{ Papua New Guinea south coast } \\
\hline Motu & honu & $\ldots$ & hode & hahine & $\ldots$ & $\ldots$ & lada- \\
\hline Mekeo & poyu & $\ldots$ & poke & papie & $\ldots$ & $\ldots$ & aka- \\
\hline \multicolumn{8}{|c|}{ Bismarck Archipelago } \\
\hline Bali-Vitu & Vonuku & Bonu & vozere & (tavine) & ¿uzaya & vatu & iza- \\
\hline Tolai & $\ldots$ & pun & vo & vavina & $\ldots$ & vat & $\operatorname{ian}$ \\
\hline Nyindrou & $\ldots$ & boi & bos & $\ldots$ & $u r$ & bek & ñara- \\
\hline \multicolumn{8}{|c|}{ Southeast Solomon Islands } \\
\hline Gela & vonu & vonu & vohe & vaivine & uha & vatu & aha- \\
\hline Lau & fupu & fonu & fote & $\ldots$ & uta & fou & hata- \\
\hline \multicolumn{8}{|c|}{ Central Pacific } \\
\hline Standard & $\ldots$ & vonu & $i-$-vode & $\ldots$ & ида & vatu & уада- \\
\hline \multicolumn{8}{|l|}{ Fijian } \\
\hline Tongan & fonu & fonu & fohe & fefine & ?uha & $\ldots$ & $\ldots$ \\
\hline
\end{tabular}

Notes

(a) A blank indicates that the appropriate cognate does not occur in the linguist's data, perhaps because the cognate has been replaced by some other word, perhaps because the linguist failed to collect the cognate due to a shift in its meaning or for some other reason.

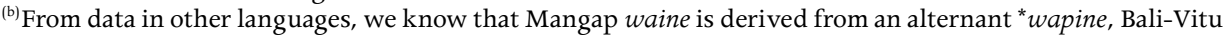
tavine from *tapine.

(c) Most of the words for 'name' have a hyphen on the end: this indicates that they normally occur with a suffix indicating the person and number of the possessor: 'my', 'thy', 'our', 'their', etc.

Having charted the sound correspondences among contemporary languages, one can infer the sound system of earlier stages by various established procedures, e.g. noting which languages retain distinct correspondences in sets of words that cannot be accounted for except by positing an original distinction. From data of which Table 1 gives only a tiny sample, Oceanic linguists are able to reconstruct the words ${ }^{3}$ *ponuq 'full', *poñu 'turtle', "pose 'paddle', *papine 'woman', 'qusan 'rain', 'patu 'stone' and *qasan 'name' for POc.

At the same time, where a word shows an apparently irregular sound correspondence, the linguist must investigate whether this is the result of an unrecognized regularity, or whether it is the result of borrowing from a language which has undergone different sound changes, or of analogical change, or perhaps simply a chance resemblance. The careful reader will notice that Nyindrou bos 'paddle' does not conform to the pattern displayed in other cognate sets, an indication that this item could be a borrowing from another Oceanic language rather than a direct continuation of the ancestral form. There are a number of cases in the Pacific of patterned irregularity, where a language shows two or more sets of correspondences, each reflecting the reconstructed sound system of POc. A classic case of this is Rotuman, studied by Biggs (1965), where there 
are three sets of correspondences: one set occurs in directly inherited words, the other two in words borrowed from Polynesian languages. Another case is Wagawaga in southeast Papua, whose vocabulary comes from two clearly different sources.

Subgrouping is usually a much harder task than establishing genetic relationship. In the Comparative Method, subgrouping is done by working out which languages share innovations relative to an earlier ancestor. ${ }^{4}$ For example, we saw in Table 1 that Lau fote 'paddle' and uta 'rain', descended from POc *pose and *qusan respectively, have undergone an innovation whereby $\mathrm{POc}{ }^{*}-s$ - has become Lau $-t$-. This innovation is one of several sound changes shared by a number of the languages of Malaita and San Cristobal (Makira) Islands in the southeast Solomons, indicating that they form a genetic subgroup, i.e. that they are probably descended from a more recent ancestor, 'Proto-Cristobal-Malaitan', in which this innovation took place.

Reconstruction and subgrouping are delicately connected: if we reconstructed POc * $t$ - instead of * $s$ - for this correspondence, then the Malaitan languages would not be innovators in this case, but the other languages in Table 1 would be instead. Comparative linguists use various techniques to work out the probable directions of phonetic change: some sound changes are generally known to be unidirectional (e.g. Manam $-r$ - from $-s$ - is an instance of a fairly common change in human language, also reflected in Latin operis, the genitive form of opus 'work'), and the reconstruction of POc ${ }^{*} s$ is also supported by non-Oceanic Austronesian languages which indicate its presence in proto-languages of higher order than POc.

Subgrouping under the Comparative Method can be applied recursively to identify subgroups within subgroups, that is, to construct what is conventionally called the "family tree" of a set of genetically related languages.

The Comparative Method produces several kinds of result in addition to subgrouping. Firstly (and we return to this in the section on kinds of subgroups) different kinds of subgroup, with different kinds of history, can be identified. Secondly, reconstructed vocabulary, and especially reconstructed terminologies, can illuminate the culture and environment of the people who used them. And thirdly, like other scholars, linguists assume that dispersal centres are most likely to be in the areas of greatest genetic diversity. Thus, if there are two primary subgroups in a family which occupy contiguous geographical areas, the most likely dispersal centre is around the geographic seam.

One thing that comparative linguists cannot do is to provide absolute dating of the linguistic splits posited in a family tree hypothesis. Reconstructing sequences of putative splits provides only relative chronologies. ${ }^{5}$ To give absolute dates to prehistoric linguistic events, we need to be able to relate them to archaeological events. 


\section{The Oceanic Subgroup and Proto-Oceanic Culture}

The linguistic evidence indicates that there was just a single early movement of Austronesian speakers into northwest Melanesia that left linguistic traces.

The need to recognize what we now call the Oceanic subgroup of Austronesian was first expressed by the Dutch linguist Hendrik Kern (1886) in a discussion of the relationships of Fijian to several Indonesian and Polynesian languages, but the foundations of modern Oceanic comparative work were not truly laid until the 1930s, when the German linguist, Otto Dempwolff, published his major work $(1934,1937,1938)$ on the Austronesian family. In the second volume of this work Dempwolff reconstructed a sound system for the immediate common ancestor of the Polynesian languages and a sample of eighty-two "Melanesian" languages and found that all the languages in his sample reflect a set of sound changes to the Proto-Malayo-Polynesian ("Uraustronesisch") system he had reconstructed earlier. The quantity of these shared phonological innovations led Dempwolff to conclude that the "Melanesian" and Polynesian languages form a subgroup apart from the Austronesian languages to the west, in the Indo-Malaysian archipelago. Dempwolff labelled the interstage language ancestral to this subgroup "Urmelanesisch". Another German scholar, Wilhelm Milke, coined the more appropriate "Proto-Ozeanisch" in 1961, and since then "Proto-Oceanic" has been used. Even though some of Dempwolff's putative phonological innovations have been eliminated as a result of subsequent research, the evidence for Oceanic has on the whole been strengthened and the precision of our phonological, grammatical and lexical reconstructions has improved. ${ }^{6}$

The region covered by "Oceania" in this context is the Pacific east of a line drawn from north to south and dividing Chamorro (Mariana Islands) and Belau (formerly Palau) from the rest of Micronesia and crossing the north coast of Irian Jaya at $138^{\circ} \mathrm{E}$ longitude. This means that the seam between Oceanic and its closest Austronesian relatives is in the west of New Guinea between the Bird's Head and the Sarmi Coast. The Oceanic subgroup includes the Austronesian languages of all of Melanesia except the extreme west of New Guinea, all of Polynesia and most of Micronesia (see Map 1). Apart from languages brought by colonialism, languages of Oceania which are not Austronesian are found only in New Guinea and nearby archipelagoes. These are the so-called non-Austronesian or "Papuan" languages of many of the peoples of New Guinea and some island peoples as far east as Savo in the Solomon Islands (and a probable outlier area in the Reef Islands).

Reconstructed Oceanic terminologies give insight into the culture of POc speakers and of the speakers of various interstage languages. ${ }^{7}$ It is clear that POc speakers preserved a very high proportion of Proto-Malayo-Polynesian and Proto-Eastern Malayo-Polynesian terms for a range of important cultural domains. The inference must be drawn that there was continuity in many components of 
the way of life of Austronesian speakers from a Proto-Malayo-Polynesian dispersal centre in Island Southeast Asia to the POc dispersal centre in northwest Melanesia, over a period of uncertain duration, perhaps 1000 years. The lexical reconstructions point to what archaeologists (e.g. Bellwood 1989) refer to as initial "founder settlement" of northwest Melanesia by Austronesian speakers.

Elaborate terminologies for seafaring and fishing and for horticulture and pottery indicate that the economy of POc speakers was based on both the sea and the land, and that some people or some local groups were specialist fishermen, farmers or potters (Pawley 1981; Pawley and Green 1984). Table 2, for example, lists reconstructed POc terms for canoe parts, seafaring and the sea (mostly from Pawley and Pawley 1994). Terms can also be reconstructed for various winds (Ross 1994d) and for numerous fish and sea creatures (Walter 1989; Pawley 1993). Table 3 shows the reconstructed forms for the growth stages of the coconut and for parts of the coconut, whilst Table 4 gives terms for food plants other than the coconut as well as some other horticultural terms (terms in both tables are from French-Wright 1983 and Ross 1993). Lichtenberk (1994) has reconstructed terms associated with food preparation (e.g. "tabiRa 'wooden dish', "qumun 'stone oven') and Ross (1994c) terms for pots and pottery; some of these are listed in Table 5. We can also reconstruct the names of various land animals ( ${ }^{*} b o R o k$ 'domesticated pig', *bawe probably 'wild pig', *kadroRa 'cuscus', " $m^{w}$ aj[oa] 'bandicoot, marsupial rat', *kasuari 'cassowary'). Reconstructed terminologies can also illuminate social organization, exemplified by the kinship terminology of Table 6 (based on Milke 1958; Chowning 1991): it is noteworthy that there is a gap in the system at 'father's sister' and that only two affinal terms have so far been reconstructed. 


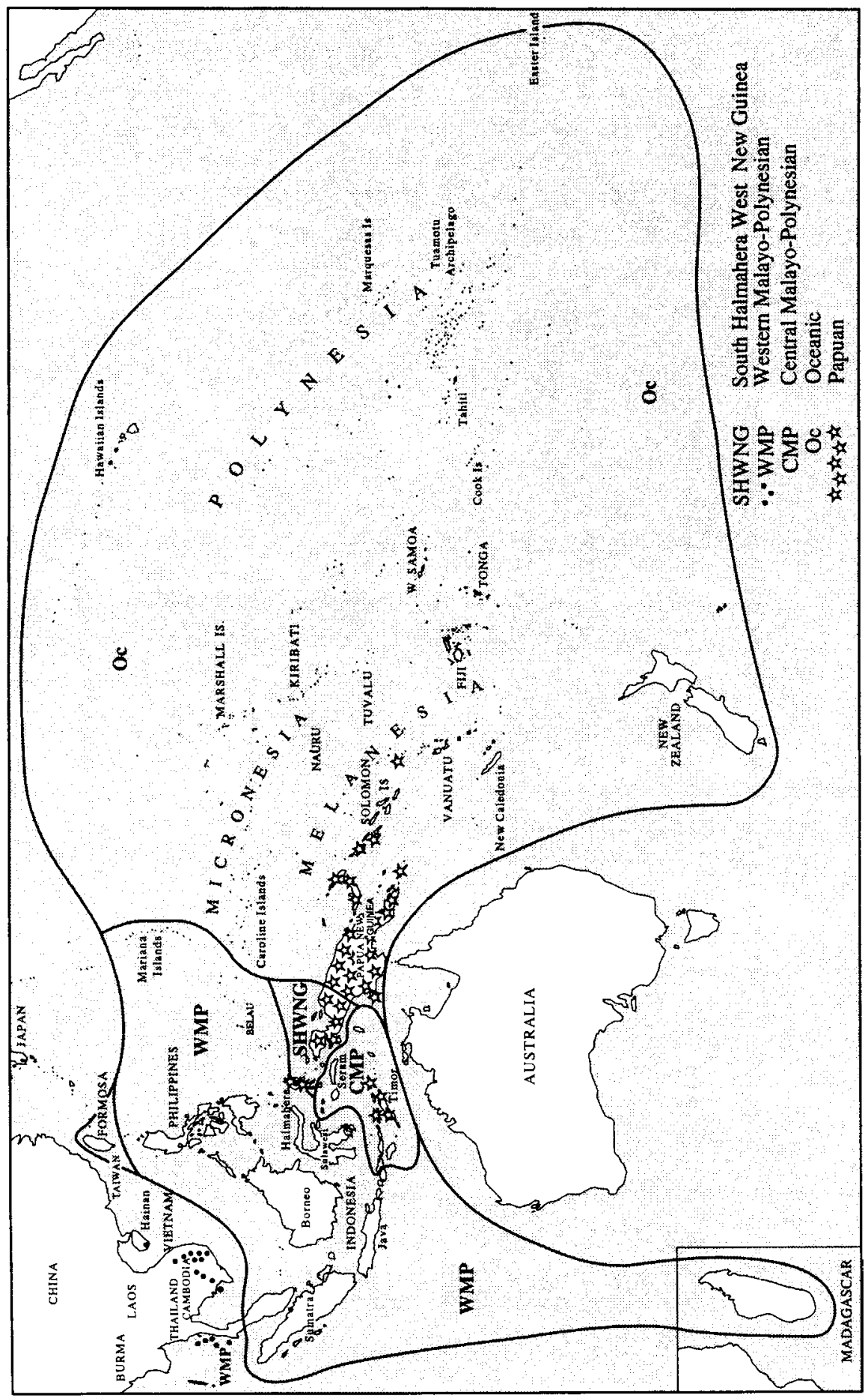

Map 1: Boundaries of the Oceanic subgroup of Austronesian languages. 


\section{Table 2. Reconstructed Proto-Oceanic terms for canoe parts and seafaring.}

\begin{tabular}{|c|c|}
\hline Types of vessel: & \\
\hline *waga & large sailing canoe; outrigger canoe (generic) \\
\hline${ }^{*} k a t i R$ & small outrigger canoe (?) or canoe hull \\
\hline \multicolumn{2}{|l|}{ Parts of a canoe: } \\
\hline *baban, *bapan & plank; canoe plank or strake \\
\hline *soka(r) & thwart; collar-beam in house \\
\hline${ }^{*}(q) o R a$ & strake, probably topstrake (washstrake) \\
\hline *pataR & platform of any kind, inc. one erected on outrigger framework \\
\hline *saman & outrigger float \\
\hline${ }^{*}$ kiajo & outrigger boom \\
\hline *patoto & connective sticks attaching float \\
\hline${ }^{*} k a t a(q) e, k a t e(q) a^{(b)}$ & free side of canoe, opposite the outrigger \\
\hline *layaR & Sail \\
\hline *qeba & mat; matting sail \\
\hline *jila & boom or yard of (triangular) sail \\
\hline${ }^{*}$ muri- & rear, stern; back of any object \\
\hline${ }^{*}$ muqa- & front, bow of boat; front of any object \\
\hline${ }^{*}$ isu- & nose; projecting headboard of prow ${ }^{(c)}$ \\
\hline * $\eta u j u-$ & snout; projecting headboard of prow ${ }^{(c)}$ \\
\hline \multicolumn{2}{|l|}{ Canoe accessories: } \\
\hline${ }^{*}$ pose & (canoe) paddle \\
\hline *paluca & to paddle \\
\hline${ }^{*} \operatorname{lima}(s), \operatorname{nima}(s)$ & bailer \\
\hline *asu & scoop or ladle out; ladle, bailer \\
\hline *layon & rollers \\
\hline *Iayon-i & place rollers under a boat \\
\hline *ujan, *Iujan & to load (a boat); cargo, freight \\
\hline *quliy & to steer; rudder \\
\hline${ }^{*} j a u(q)$ & be anchored or moored, be stationary \\
\hline \multicolumn{2}{|l|}{ Canoe making: } \\
\hline${ }^{*}$ kiRam & adze/axe \\
\hline${ }^{*} t a R a q$ & adze \\
\hline${ }^{*}$ taRaq-i & to adze, carve \\
\hline
\end{tabular}

Notes

${ }^{(a)}$ In this and the following tables reconstructions are given in the orthography of Ross (1988), with the addition of the phoneme ${ }^{*} p^{w}$. Conventions in proto-forms are:

$(x)$ it cannot be determined whether $x$ was present;

$(x, y), x x / y y$ either $x$ or $y$;

$[x]$ the item is reconstructible in two forms, one with and one without $x$;

$[x, y]$ the item is reconstructible in two forms, one with $x$ and one with $y$;

$x x, y y$ both $x$ and $y$.

$-x x \times x$ is always suffixed (in most cases by an inalienable possessor suffix).

(b) The parentheses indicate that the ${ }^{*}-q$ - is not reflected in our data, but is required by the rules governing the canonic form of POc words.

${ }^{(c)}$ Often with ornately carved figurehead. 
Table 3. Reconstructed Proto-Oceanic forms associated with coconut culture.

The coconut and its stages of growth:

\begin{tabular}{|c|c|}
\hline${ }^{*}$ niuR & $\begin{array}{l}\text { coconut (generic); growth stage: ripe, brown but not fallen } \\
\text { yet }\end{array}$ \\
\hline$*^{*}(q) a b^{w} a j i$ & growth stage: fruit bud \\
\hline${ }^{*} k u b o /{ }^{*} k u b^{w} a$ & growth stage: young, green \\
\hline${ }^{*}$ karu & growth stage: green, drinkable \\
\hline${ }^{*}$ matuqu & growth stage: ripe, brown but not fallen yet \\
\hline${ }^{*}$ maRayo, *goRu & growth stage: dry and ready to fall \\
\hline${ }^{*} t a b^{w} a$ & growth stage: sprouted \\
\hline \multicolumn{2}{|c|}{ Parts of the coconut palm and of the coconut: } \\
\hline *polo & coconut water \\
\hline${ }^{*} b^{w}$ ilo, lasa & coconut shell used as liquid container or cup \\
\hline *paraq & coconut embryo \\
\hline *puto- & spongy centre of a sprouting coconut \\
\hline *punut, ${ }^{*}$ penut & coconut husk, fibres on coconut husk \\
\hline${ }^{*}$ kojom[-i] & to husk a coconut \\
\hline${ }^{*}[p a] p a q[a-]$ & frond of a palm \\
\hline *palapa $(q)$ & palm branch \\
\hline *suluq & dry coconut leaf torch \\
\hline${ }^{*}$ Runut, ${ }^{*}$ nuRut & sheath around base of coconut frond, used as a strainer \\
\hline
\end{tabular}


The Austronesians: Historical and Comparative Perspectives

\section{Table 4. Reconstructed Proto-Oceanic terms for horticulture and food plants (other than coconuts)}

\begin{tabular}{|c|c|}
\hline \multicolumn{2}{|c|}{ Tubers and their culture: } \\
\hline${ }^{*} m^{w} a p o(q)$ & taro (possibly all Araceae) \\
\hline${ }^{*}$ talo(s) & taro, Colocasia esculenta \\
\hline${ }^{*}$ piRaq & giant taro, elephant ear taro, Alocasia macrorrhiza \\
\hline *bulaka & swamp taro, Cyrtosperma chamissonis \\
\hline${ }^{*} \mathrm{kam}^{\mathrm{w} a}$ & k.o. wild taro (?) \\
\hline${ }^{*}$ qupi & greater yam, Dioscorea alata; yam (generic) \\
\hline${ }^{*} p^{w}$ atik & potato yam, aerial yam, Dioscorea bulbifera \\
\hline${ }^{*}(s, j) u l i(q)$ & banana or taro sucker, slip, cutting, shoot (i.e. propagation material) \\
\hline${ }^{*}$ wasi $(n)$ & taro stem (used for planting) \\
\hline${ }^{*} b^{w} a y o$ & new leaves or shoots, or taro tops for planting \\
\hline${ }^{*} u p(e, a)$ & taro seedling \\
\hline${ }^{*}$ pasoq $[-i]$ & to plant (tubers) \\
\hline${ }^{*}$ kotin & to cut off taro tops \\
\hline \multicolumn{2}{|l|}{ Bananas: } \\
\hline${ }^{*}$ pudi & banana, Musa cultivars \\
\hline *joRaga & banana, Australimusa group \\
\hline *sakup & k.o. cooking banana: long with white flesh (presumably Eumusa group) \\
\hline \multicolumn{2}{|c|}{ Other food plants: } \\
\hline *topu & sugar cane, Saccharum officinarum \\
\hline * pijo & a kind of edible wild cane or a reed, Saccharum spontaneum \\
\hline *[ka]timun & cucurbit (generic); cucumber, Cucumis sativus \\
\hline *laqia & ginger, Zingiber officinale \\
\hline *yayo & turmeric, Curcuma longa \\
\hline${ }^{*}$ kuluR & breadfruit, Artocarpus altilis \\
\hline *baReqo & breadfruit fruit (?) \\
\hline *padran & pandanus (generic); coastal pandanus, Pandanus tectorius \\
\hline${ }^{*}$ kiRe & coastal pandanus, Pandanus tectorius \\
\hline *pakum & Pandanus dubius \\
\hline *ima & k.o. pandanus with useful leaves \\
\hline *Rabia & sago, Metroxylon spp., mainly Metroxylon sagu \\
\hline${ }^{*} \operatorname{sag}(u)$ & sago starch \\
\hline *qatop & sago fronds, thatch \\
\hline${ }^{*}$ talise & Java almond, Indian almond, Terminalia catappa \\
\hline${ }^{*}$ qipi & Tahitian chestnut, Pacific chestnut, Inocarpus fagifer \\
\hline${ }^{*}[k a] \eta a R i$ & canarium almond, Canarium spp. \\
\hline${ }^{*}$ molis & citrus fruit or citrus-like fruit \\
\hline${ }^{*} \operatorname{pau}(q)^{*}$ & mango, probably Mangifera indica \\
\hline${ }^{*}$ wai, *waiwai & mango (generic) \\
\hline${ }^{*}$ kapika & Malay apple and rose apple, Eugenia spp. \\
\hline * ñonum & Morinda citrifolia \\
\hline *tawan & Pometia pinnata \\
\hline *wasa & edible greens, Abelmoschus manihot \\
\hline$\left.{ }^{*} \mathrm{~m} /{ }^{\mathrm{w}}\right)$ asoku & wild cinnamon, Cinnamomum spp. \\
\hline *quRis & Polynesian plum, hog plum, Tahitian apple, Spondias cytherea \\
\hline${ }^{*} \tilde{n a t u}(q)$ & k.o. tree with avocado-like fruit and hard wood, Burckella obovata \\
\hline${ }^{*} \operatorname{raqu}(p)$ & New Guinea walnut, Dracontomelon dao \\
\hline *buaq & areca palm, Areca catechu \\
\hline \multicolumn{2}{|c|}{ Gardening practices: } \\
\hline *quma & garden \\
\hline
\end{tabular}




\begin{tabular}{ll}
\hline${ }^{*}$ tanoq & soil, earth \\
${ }^{*}$ poki & to clear ground for planting \\
${ }^{*}$ sara & to dig a hole \\
${ }^{*}$ tanum[-i] & to plant \\
\hline
\end{tabular}

Some prehistorians evidently find the methods of historical linguistics so arcane or the idea of such detailed lexical reconstructions so incredible, that they prefer to ignore or discount the reconstructions as irrelevant to prehistory. This attitude is no more excusable than that of a linguist who would ignore $\mathrm{C}^{14}$ dates for artefact assemblages because he does not understand how such dates are arrived at or who would discount the relative dating of assemblages in any archaeological site on the suspicion that worms, humans or earthquakes have disturbed the layers.

Table 5. Reconstructed Proto-Oceanic terms associated with pots and pottery.

\begin{tabular}{|c|c|}
\hline \multicolumn{2}{|c|}{ Types of vessel: } \\
\hline *kuron & cooking pot, pot (generic) \\
\hline *palaya & frying pan \\
\hline${ }^{*} b^{w} a \eta a$ & k.o. large pot \\
\hline \multicolumn{2}{|c|}{ Parts of vessel: } \\
\hline${ }^{*}$ tupa $((n, y))$ & lid, cover \\
\hline *joya $(n, \eta)$ & plug, bung, stopper \\
\hline${ }^{*} m^{w} a t i$ & herringbone pattern \\
\hline \multicolumn{2}{|c|}{ Pottery manufacture: } \\
\hline${ }^{*} r a R o(q)$ & clay \\
\hline${ }^{*}$ buli & mould (clay etc.) \\
\hline${ }^{*}$ tapi & paddle for beating clay into shape \\
\hline${ }^{*}$ pilit & coil around, encircle; add strip of clay around top of pot \\
\hline \multicolumn{2}{|l|}{ Pottery use: } \\
\hline${ }^{*}$ tunu & roast in the fire, fire (pot) \\
\hline${ }^{*}$ nasu & cook by boiling \\
\hline${ }^{*}$ napu & steam, boil \\
\hline *rapu & fireplace \\
\hline
\end{tabular}

Table 6. Reconstructed Proto-Oceanic kinship terms.

\begin{tabular}{ll}
\hline Consanguineal terms: & \\
\hline${ }^{*}$ t[i,u]bu- & grandparent, grandchild \\
${ }^{*}$ makubu & grandchild \\
${ }^{*}$ tama- & father, father's brother \\
${ }^{*}$ tina- & mother, mother's sister \\
${ }^{*}$ matuqa & mother's brother \\
${ }^{*}$ (qa)lawa & mother's brother, sister's child \\
${ }^{*}$ natu- & child, same-sex sibling's child \\
${ }^{*}$ tuqaka- & older same-sex sibling \\
${ }^{*}$ taci- & younger same-sex sibling \\
${ }^{*}{ }^{w}$ aqane & brother (woman speaking) \\
${ }^{*}$ (pa)pine & sister (man speaking) \\
Affinal terms: & \\
${ }^{*}$ qasawa- & spouse \\
${ }^{*}$ qipaR & spouse's opposite-sex sibling \\
\hline
\end{tabular}

Note: The problem of reconstructing two terms for 'mother's brother' is discussed by Chowning (1991:65). 


\section{The Dispersal and Diversification of Oceanic Languages}

Subgrouping: the sequence of genetic splits in Oceanic

\section{Kinds of subgroups.}

Innovations occur in two basic patterns across languages, enabling linguists to identify subgroups. In the first pattern, all member languages of a subgroup exclusively share a common set of innovations. In the second pattern, innovations form an overlapping pattern, such that, for example, languages $\mathrm{A}, \mathrm{B}$ and $\mathrm{C}$ reflect one bunch of innovations, languages $\mathrm{C}, \mathrm{D}$, and $\mathrm{E}$ another bunch, languages $\mathrm{D}$, E, F, and $G$ yet another, and languages $G$ and $H$ still a different bunch of innovations. A subgroup reflecting the first pattern may be termed an "innovation-defined" subgroup. One reflecting the second pattern may be called an "innovation-linked" subgroup. ${ }^{8}$

The two patterns allow linguists to make certain inferences about how languages have diverged. ${ }^{9}$

In the case of an innovation-defined subgroup, we infer that all member languages of the subgroup exclusively share a set of innovations because these innovations occurred in the language ancestral to them. That is, the subgroup has been formed because a community speaking a single language has become separated geographically and/or socially into two or more communities; after separation, changes have occurred in the speech of each of the new communities until what was one language has become two or more.

The inference that can be made about an innovation-linked subgroup is of a different order. Here, it can be inferred that the overlapping pattern of innovations reflects the fact that the languages of the subgroup once formed a network of related dialects. During this phase, innovations occurred at various places in the network, spreading from their dialect of origin into neighbouring dialects, but without affecting the whole network. Over time the dialects have diverged until they have become mutually unintelligible for practical purposes, but they continue to reflect the innovation pattern of the former network. ${ }^{10}$

Innovation-defined and innovation-linked subgroups are not mutually exclusive. A subgroup may be both: innovation-defined in that there are innovations shared by all members of the subgroup, and innovation-linked because there is also a pattern of overlapping innovations. In such a case, both sets of inferences apply. The subgroup is innovation-defined because its member languages are descended from a single interstage language, and innovation-linked because that interstage language diversified into a dialect network out of which the present-day languages have evolved.

With the small size and geographical isolation of political entities in Oceania, dialect networks have readily become innovation-linked subgroups of discrete 
languages. The result is that innovation-linked subgroups are important in Oceanic historical linguistics. But they are also problematic. The internal structure of an innovation-linked subgroup is known to us through its patterning of innovations, but, unless the subgroup is also innovation-defined, we have no direct evidence as to its origin: it may be descended from a discrete interstage language which happens not to have undergone an identifiable set of innovations, or it may simply be descended from a detached section of an earlier dialect network.

In the 1950s and 1960s, comparative linguists writing in the Austronesian field saw their primary task as genetic classification and reconstruction, and applied a simple-minded family tree model in which all language splits are assumed to be sudden and complete. But a family-tree model is often unsatisfactory for making sense of and for representing historical relationships among languages. One reason is that it forces those linguistic relationships produced by dialect differentiation (and subsequent break-up of the network) into a distorted scenario, that of the sharp separation model - and in early Oceanic, dialect differentiation and network-breaking were the rule rather than the exception. Since the early 1970s Austronesianists have given more attention to the problem of dialectal diffusion in prehistoric languages. In the Oceanic field the most incisive study of this kind is Geraghty's (1983) treatment of the relationship of the Fijian speech traditions to each other and to Polynesian. Other works that tackle dialect diffusion in particular regions include Pawley (1975) and Ross (1994b) on Central Papua; Ross (1988) on various regions of western Melanesia; Lichtenberk (1988) on Malaita; Clark (1985) and Tryon (1976) on Vanuatu; Pawley and Sayaba (1971) on Fiji; Pawley (1979) on Fiji and Rotuma; Biggs (1980), Dyen (1981) and Rensch (1987) on western Polynesia; and Jackson (1983) and Marck (1986) on Nuclear Micronesia.

The Comparative Method is not equipped to investigate certain kinds of historical change, such as structural convergence resulting from bilingualism, or from "drift" (pressures inherent in certain structural types that allegedly favour parallel changes). Recent work has begun to address these phenomena using a range of methods (e.g. Thurston 1987; Ross 1987; Ross forthcoming; and a number of the papers in Dutton and Tryon 1994).

\section{High-order subgroups.}

The following high-order subgroups of Oceanic seem fairly well supported: ${ }^{11}$

1. Admiralty Islands

2. St Matthias Islands

3. Western Oceanic

4. Southeast Solomonic

5. North/Central Vanuatu 


\section{South Vanuatu \\ 7. Southern Oceanic \\ 8. Central Pacific \\ 9. Nuclear Micronesian}

The regions covered by these groups are shown in Map 2. We are not seeking to claim that POc underwent a primary nine-way split, but simply that in our view persuasive arguments have yet to be presented for higher-order groupings. ${ }^{12}$ It should be noted that Groups 3, 5 and 8 are innovation-linked subgroups: there is no innovation which all their members share relative to POc.

The Admiralties group is clearly established as an innovation-defined subgroup (Blust 1978b; Ross 1988:ch. 9). The St Matthias group is also innovation-defined, with the possibility that it is associated in some way with the Admiralties; it certainly is not a close relative of its southern neighbours, the languages of New Ireland (Ross 1988:ch. 9).

The Western Oceanic grouping was proposed as an innovation-linked subgroup by Ross (1988:386-389). Except in a few small relic areas the languages of the region merge POc ${ }^{*} r$ and ${ }^{*} R$, share reflexes of the innovative disjunctive pronoun *idri [a] 'they' (in contrast to POc * $(k)$ ira), and sporadically reflect other features which imply that the languages of the region are descended from a dialect network which has a history separate from that of other Oceanic groups.

The Southeast Solomonic group is a fairly well innovation-defined and apparently very conservative subgroup, which divides in its turn into the Guadalcanal/Gela and Malaita/Makira subgroups (Pawley 1972; Levy 1979, 1980; Tryon and Hackman 1983; Lichtenberk 1988).

North/Central Vanuatu is an innovation-linked subgroup which has been documented by Pawley (1972), Tryon (1976) and Clark (1985). Clark views the subgroup as the outcome of a dialect network which gradually differentiated out into local languages. He recognizes a major division between North and Central Vanuatu, "with the boundary running between Santo and Malekula and between Raga and the remainder of Pentecost" (1985:221).

The South Vanuatu group embraces the languages of the islands of Erromanga, Tanna and Aneityum, and is an innovation-defined subgroup documented by Lynch (1978).

Geraghty (1989) has proposed a New Caledonian group (he calls it "Southern Oceanic") which includes all the languages of New Caledonia and the Loyalty Islands. He also suggests that New Caledonian may subgroup with South Vanuatu, and implies that this grouping may form an innovation-linked subgroup with North/Central Vanuatu. ${ }^{13}$ However, the evidence for this is limited and in our view not yet persuasive. 
The Central Pacific grouping has been well studied (Grace 1959; Pawley 1972; Geraghty 1983, 1986, 1990). Proto-Central Pacific was evidently located in the Fijian archipelago, where it became differentiated into a dialect network with considerable variation from east to west. Speakers of an eastern dialect separated, probably by moving to Tonga and other islands in western Polynesia, where Proto-Polynesian developed (Geraghty 1983; Green 1981). Speakers of a western dialect moved to Rotuma, where a distinct language developed (Pawley 1979). Subsequently, the stay-at-home dialects in Fiji continued to interact, so that they now form an innovation-linked group, within which an eastern and a western subgroup are clearly distinguishable (Pawley and Sayaba 1971; Geraghty and Pawley 1981; Geraghty 1983). Proto-Polynesian has diversified into the languages of the Polynesian group, a very well defined subgroup of Oceanic (Pawley 1966, 1967; Biggs 1971). 


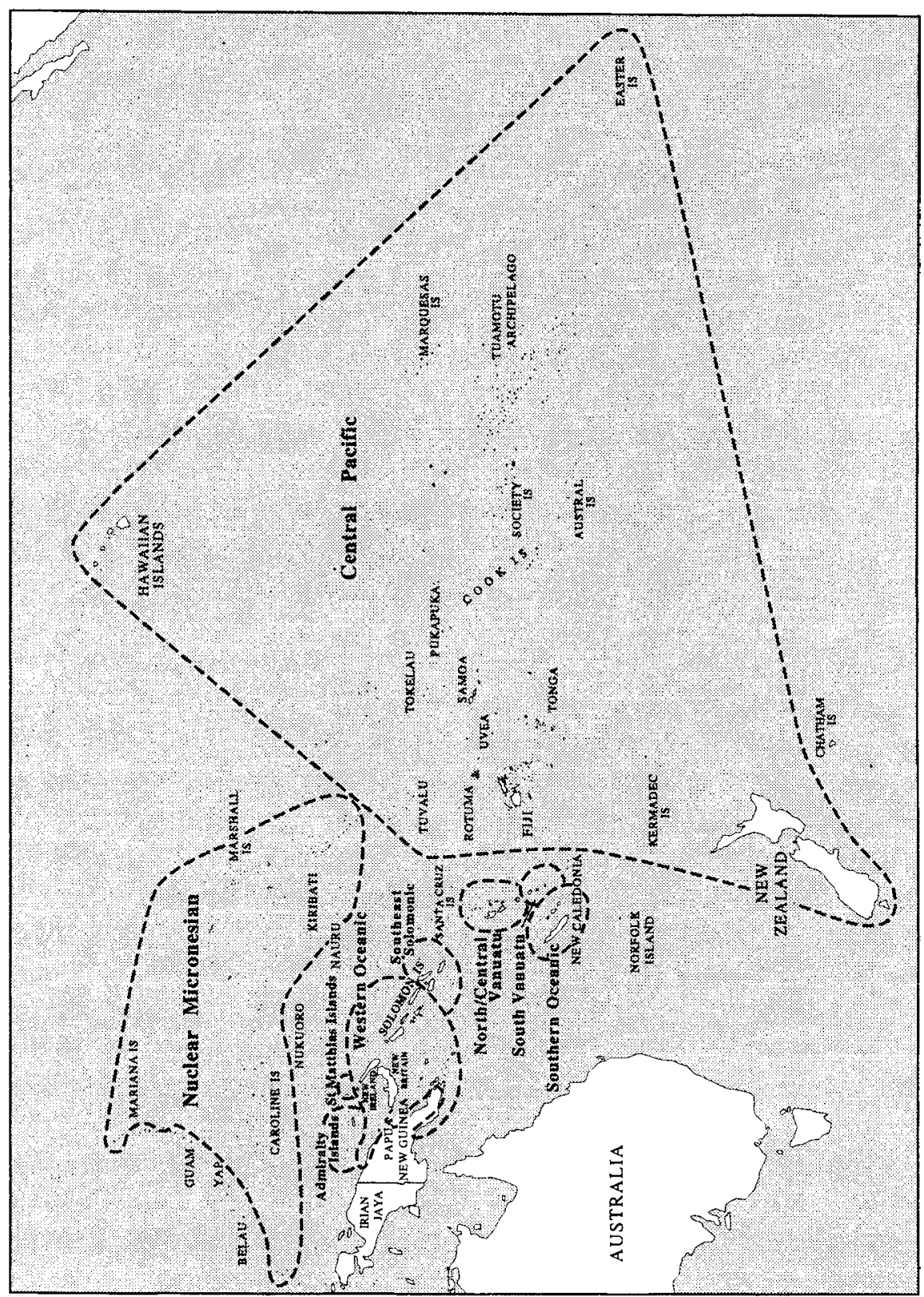

Map 2: High-order subgroups of Oceanic Austronesian languages.

Nuclear Micronesian includes all languages of Micronesia except Belau, Chamorro and probably Yapese (Bender 1971; Jackson 1983; Bender and Wang 1985). ${ }^{14}$ 


\section{Subgroups of Western Oceanic.}

Ross (1988) proposes that the Western Oceanic group is made up of three subgroups or "clusters": Meso-Melanesian, Papuan Tip and North New Guinea (see Map 3). ${ }^{15}$ The first two of these are innovation-defined subgroups, and in both cases the interstage proto-language or an early daughter interstage evidently differentiated into an extensive network. The North New Guinea grouping, however, is an innovation-linked subgroup, in that there are no innovations shared by all languages of the cluster relative to POc (Ross 1988:120). Instead, the cluster consists of three innovation-defined groups (Ngero/Vitiaz, Huon Gulf and Schouten), each defined by a set of shared innovations and each including lower-order subgroups (see Map 4). One or more subgroups within each innovation-defined group also has some innovations which it shares with one or more subgroups of the other two innovation-defined groups, joining the three in a network relationship. ${ }^{16}$

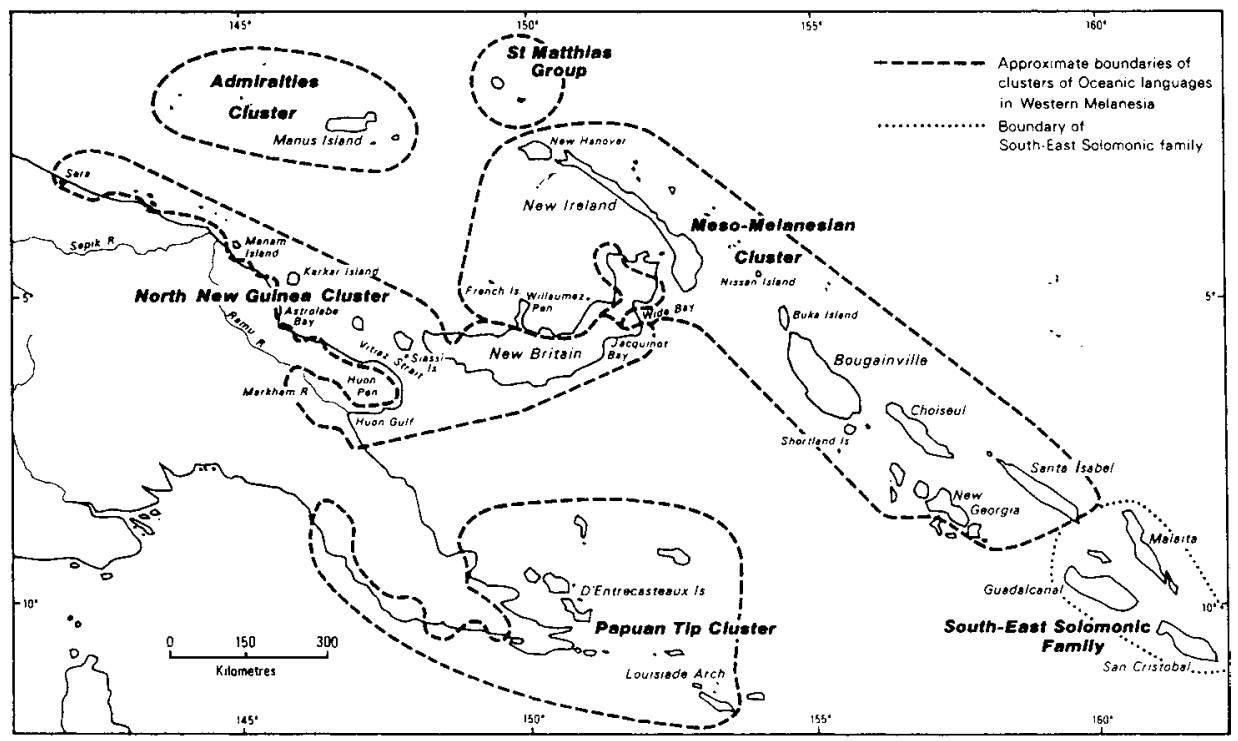

Map 3: Oceanic subgroups in western Melanesia. 


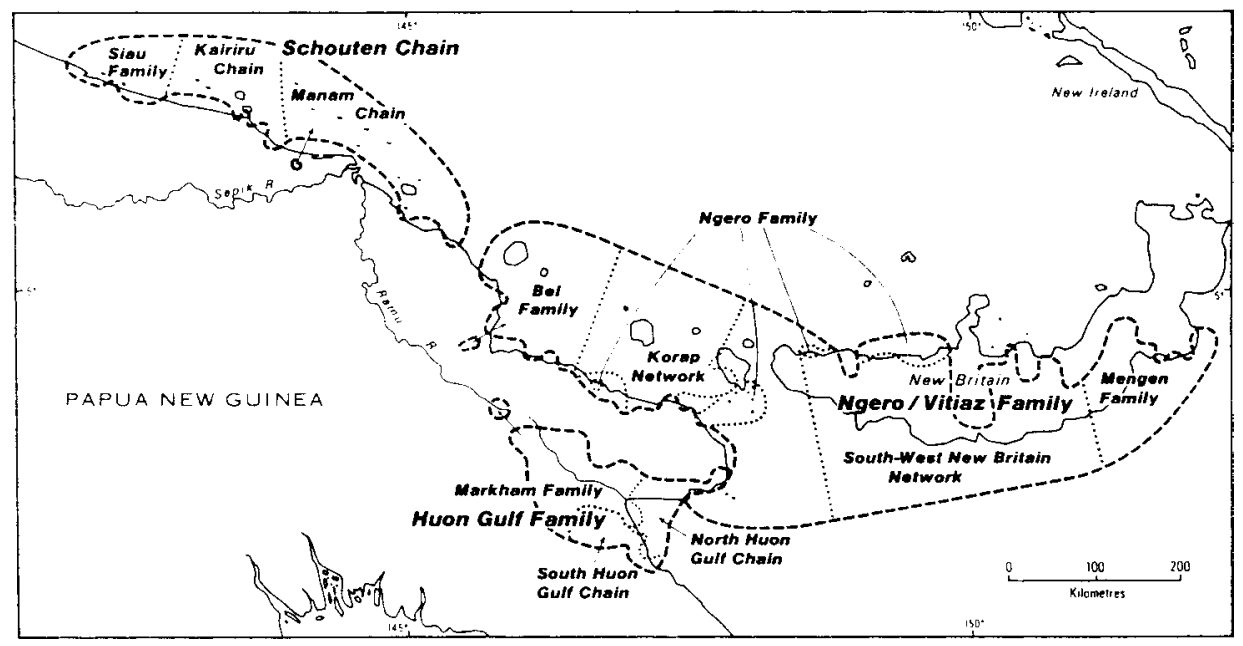

Map 4: The North New Guinea grouping and its subgroups.

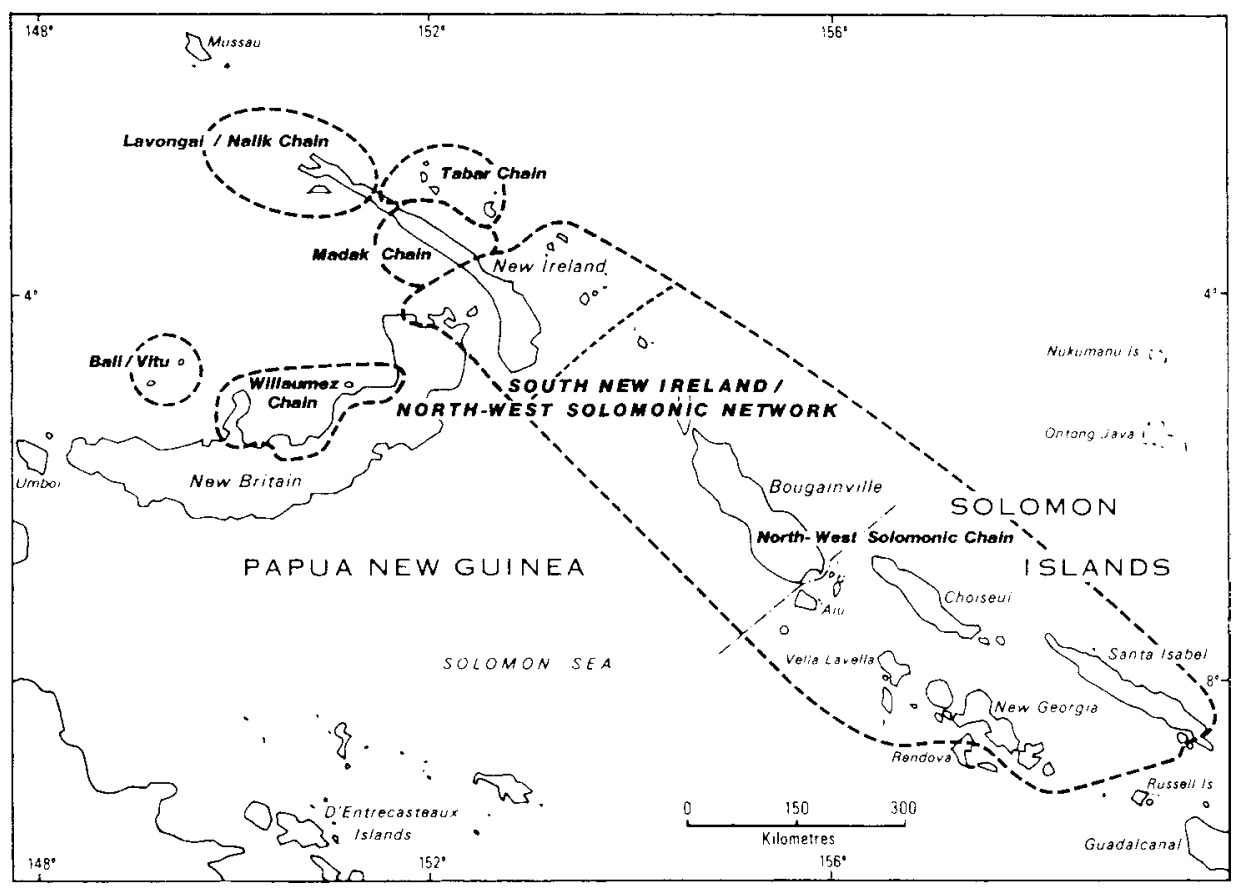

Map 5: The Meso-Melanesian grouping and its subgroups.

The internal structure of the Meso-Melanesian subgroup (Map 5) is very complex. A primary three-way split into the Bali-Vitu language, the Willaumez chain, and the New Ireland/Northwest Solomonic linkage (stretching from New Hanover to Santa Isabel) is recognizable. The latter in its turn seems to comprise the Madak, Tabar and Lavongai/Nalik groups which occupy central and northern 
New Ireland and the far-flung South New Ireland/Northwest Solomonic linkage. However, since the departure from southern New Ireland (we assume) of those whose descendants became the speakers of Northwest Solomonic languages, the languages the whole length of New Ireland have continued to interact so that they form an innovation-linked group. The New Ireland communalects have thus behaved similarly to those of Fiji.

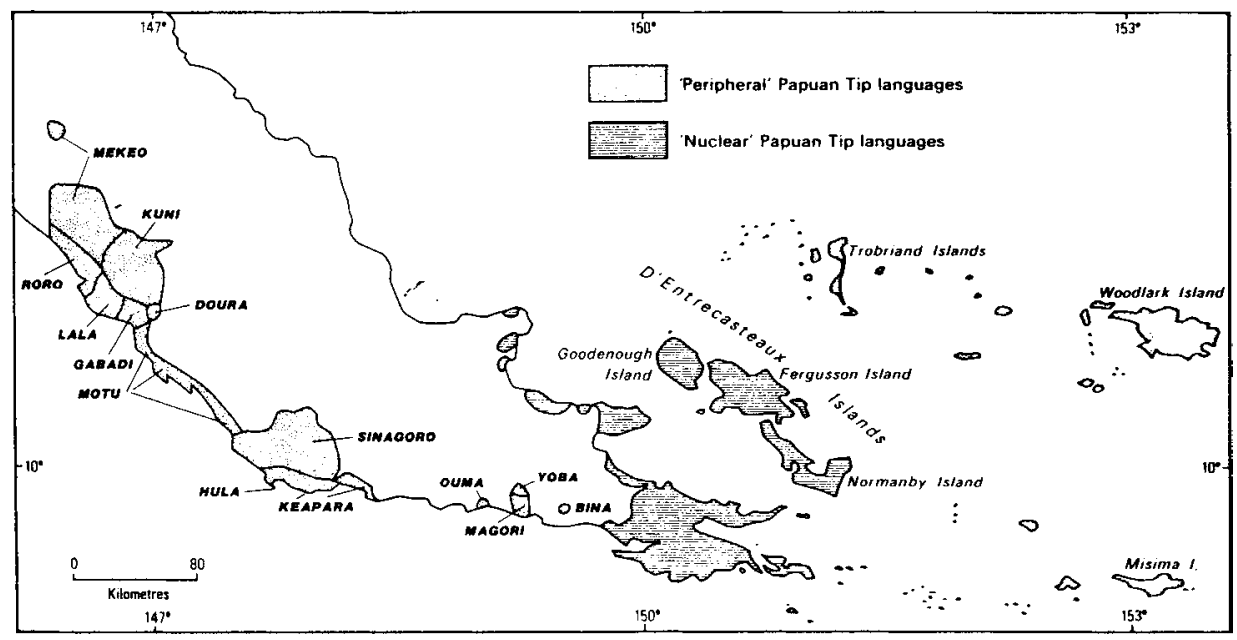

Map 6: The Papuan Tip grouping and its major subgroups.

The structure of the Papuan Tip subgroup (Map 6) is less complex. There is a possible (but not particularly well supported) initial split into "Nuclear" and "Peripheral" Papuan Tip linkages. The languages of the Nuclear network split into the Suauic chain (located mostly on the southeastern-most portion of the mainland) and the North Mainland/D'Entrecasteaux network, which forms a rough arc stretching from Normanby Island, through Fergusson and Goodenough Islands to the mainland coast at Collingwood Bay, then southeastwards along and around the coast as far as Milne Bay (Ross 1988:191, 1992).

"Melanesia". The reader will notice that nowhere do we speak of "Melanesian" languages or a "Melanesian" group. In describing the location of the Oceanic languages, one cannot avoid "Melanesia" as a geographic term. Nowadays, however, the comparative linguist referring to the genetic grouping of languages recognizes no such adjective as "Melanesian". Melanesia is occupied, as we have noted, by speakers of both Papuan and Austronesian languages, but even among Austronesian languages there is no "Melanesian" group. Instead, some languages spoken in Melanesia are more closely related to Polynesian languages than to other languages of Melanesia. 


\section{Locating the POc language community and directions of dispersal}

One method for locating the probable dispersal centre (or "homeland") of a family of languages is distributional. The view that the most likely dispersal centre for a family of languages is in the area of their greatest genetic diversity was stated by Sapir (1916) some years before Vavilov applied a parallel idea to cultivated plants. More recently, its linguistic application has been substantially refined by Dyen (1956). Underlying it is the principle of parsimony, which requires that one posits the fewest and shortest moves needed to account for the geographic distribution of the subgroups. It can be seen that this method depends on subgrouping, because genetic diversity is defined in terms of subgroups.

One needs to look at both the external relationships and the internal subgrouping of the languages in question. We accept Blust's (1978a, 1983-84, 1993) conclusions that Oceanic belongs to an Eastern Malayo-Polynesian group whose other members are found around Cenderawasih Bay in northwest New Guinea and in South Halmahera, and that the closest relatives of Eastern Malayo-Polynesian also lie in Indonesia. Given this, the method requires us to conclude that Proto-Eastern Malayo-Polynesian was probably located around Cenderawasih Bay and that the separation of the Oceanic branch began with a movement of Eastern Malayo-Polynesian speakers from Cenderawasih Bay eastwards along the north coast of New Guinea.

But where did this pre-Oceanic movement end up? That is to say, what was the dispersal centre of POc itself? The internal subgrouping outlined in the section on subgrouping allows for two main possibilities, both located in northwest Melanesia. (Map 2 gives the location of high-order subgroups of Oceanic.) One possibility is that pre-Oceanic speakers moved only as far as the Sarmi Coast or Jayapura, because here we find two small and little studied Oceanic groups which may be first-order branches of Oceanic.

But if, as the limited available evidence suggests, these groups belong to Western Oceanic, then POc developed further east, in the Bismarck Archipelago, where several fairly well-established high-order subgroups meet. In the Bismarck Archipelago we find two first-order groups of Oceanic, Admiralties and Western Oceanic, and perhaps a third, St Matthias. Western Oceanic in turn divides into three large second-order groups, two of them represented in New Britain: the North New Guinea group and the Meso-Melanesian group.

Another procedure for locating linguistic dispersal centres is often called the Wörter und Sachen ("words and things") method, because it depends on reconstructing words for things associated with culture and physical environment. For POc, for example, it is necessary to reconstruct terms for a number of animals - cassowary, possum and bandicoot - that are found in New Guinea and at locations in the Bismarck and Solomon archipelagoes, but 
which are absent from southern Melanesia, Micronesia and Polynesia. These reconstructions are required not only because the cognate sets are represented in more than one primary subgroup of Oceanic but also because cognates are found in non-Oceanic Austronesian languages in eastern Indonesia (Blust 1982). It is also necessary to reconstruct words for many marine animals and other features associated with the sea. However, this line of evidence hardly allows any conclusion more specific than that POc speakers lived near the sea somewhere in eastern Indonesia, New Guinea or the Bismarck Archipelago.

Let us turn now to the break-up of POc. Primarily on the basis of distribution of subgroups, we have placed the likely dispersal centre in the Bismarck Archipelago, without favouring any particular part of this region. The distribution of first-order subgroups indicates a more or less contemporaneous movement of POc speakers in several directions over a considerable area of Melanesia. Assuming that POc was not located in the Admiralties (an assumption which needs further investigation) there was an early movement to that region, contemporaneous with the break-up of POc. The same can be said of the St Matthias group and New Britain, each of which contains a high-order subgroup of Oceanic. At about the same time there were one or more movements into the Solomons and into Remote Oceania, leading to the divergence of the Southeast Solomonic, North/Central Vanuatu, Southern Vanuatu, Southern Oceanic, Central Pacific and Nuclear Micronesian groups.

New Britain is the likely dispersal centre for the Western Oceanic group (Ross 1989). Western Oceanic is an innovation-linked subgroup, but the two innovations noted earlier are shared by the vast majority of its member languages, suggesting that it is descended from a dialect network which once occupied quite a limited area (otherwise the innovations would not have spread through almost all the network). The available evidence indicates that this area was along the north coast of New Britain, perhaps straddling the Willaumez Peninsula, as this is the seam of two primary divisions of Western Oceanic, the Meso-Melanesian and North New Guinea groups. Furthermore, the area of greatest diversity of the Meso-Melanesian group is found in this area. Two of its three primary subgroups (Bali-Vitu and the Willaumez chain) are situated around the Willaumez Peninsula.

If the Western Oceanic homeland was on the north coast of New Britain, Western Oceanic speakers expanded in two main directions. There was progressive occupation of the New Britain coast, of New Ireland (apparently from south to north) and of the Northwest Solomonic area to form the Meso-Melanesian group. ${ }^{17}$ The second direction of expansion was across the Vitiaz Strait to the mainland coast of New Guinea. This last movement was soon followed by a split between the North New Guinea group, occupying parts of the north coast of New Guinea and offshore islands in the Morobe, Madang and 
Sepik Provinces, and the Papuan Tip group, comprising the Milne Bay and Central Province languages. Within a short time the ancestral North New Guinea network split into the Schouten, Ngero/Vitiaz and Huon Gulf groups. Sequences of reconstructible innovations particularly support the south to north settlement of New Ireland and the east to west settlement of the Schouten Islands.

The weight of the subgrouping evidence, then, points to a quite rapid diaspora of Austronesian speakers across Melanesia and into the central Pacific. We have noted distributional evidence for an approximately coeval occupation by Oceanic speakers of New Britain, St Matthias, the Admiralties, the Southeast Solomons and several regions of "Remote Oceania" (the widely separated island groups and isolated islands of the Pacific beyond the Solomons chain).

Can this dispersal be accurately dated? An association between the spread of Oceanic languages and Lapita pottery and associated artefacts in the central Pacific has been argued by a number of scholars since the 1960s, but Shutler and Marck (1975) were perhaps the first to argue that the break-up of POc itself should be associated with the movements of Lapita bearers, a view that has gained increasing acceptance (Pawley and Green 1984; Spriggs 1984, 1993; Kirch 1984, 1992; Bellwood 1989; Green 1994). Lapita pottery appears in the Bismarck Archipelago around 1600 BC (Kirch and Hunt 1988; Spriggs 1989, 1990, this volume) and in several regions of Remote Oceania soon after. Archaeological dates for the first Lapita assemblages in New Caledonia, Vanuatu, Fiji, Tonga and Samoa are all between 1300 and 1000 BC. Current archaeological dates indicate that settlement of the Papuan Tip area may not have occured until somewhat later, reaching Central Papua about 2000 years ago (Vanderwal 1973; Allen 1977a, 1977b; Bulmer 1982). At present the earliest dates which we can associate with confidence with North New Guinea speakers (on the north New Britain coast west of the Willaumez Peninsula, and on the islands and the mainland coast of the Vitiaz Strait) are only about 1500 years ago (Lilley 1988, 1990).

Rapidity of settlement bears on the conundrum of how Polynesians and Micronesians, with their Southern Mongoloid physical type, could have come out of Melanesia, where the so-called "Melanesian" physical type, marked superficially by tightly frizzy hair, dark skin and relatively large teeth, is allegedly dominant. The answer appears to be that they did not "come out of" Melanesia: some Oceanic speakers moved through Melanesia into the central Pacific, and they moved through rapidly enough to retain their Southern Mongoloid phenotype. Today's Austronesian speakers in Melanesia have acquired Melanesian characteristics in varying degrees by intermarriage in the intervening millennia and by gene flow after the initial dispersal of Oceanic speakers. ${ }^{18}$ However, even in western Melanesia, pockets of Austronesian speakers' superficial Southern Mongoloid features are still found, e.g. in much of southeast 
Papua, and on Wuvulu and Aua. Recent work in biological anthropology (referred to in Green 1994:38) indicates that other Austronesian-speaking populations in Melanesia also exhibit genetic markers linking them with Southern Mongoloid peoples of Southeast Asia and Polynesia.

\section{Modes of Oceanic dispersal}

The fact that so many Oceanic subgroups as far east as Fiji form linkages rather than families suggests that within each major island group the main mode of settlement was a continuous expansion into neighbouring territory that resulted again and again in the formation of dialect chains and networks. Each new village maintained contact with its parent village, and only gradually did village speech communities differentiate out into separate languages. The main variation in this pattern was caused by factors which hindered contact, whether geographical (a large ocean gap or a land barrier such as a mountain range) or social (the intervention of a Papuan-speaking group). The Northwest Solomonic case is instructive. Choiseul, the New Georgia group, and Santa Ysabel are each occupied by linkages within which there are no radical breaks, yet the breaks between each network, corresponding with the intervening sea, are fairly clear. On the island of Bougainville, on the other hand, the Austronesian languages show considerable differences among themselves, a product of their separation by Papuan-speakers.

There are some, but not many, notable exceptions to this pattern. For example, within the North New Guinea group the Schouten chain is sufficiently different from its neighbours to the east, and its easternmost members are sufficiently conservative in their phonology and verbal morphology (Ross 1988: 122-132) to imply that Proto-Schouten was an early departure from the North New Guinea dialect network and became completely isolated from it.

\section{Change in the Lexicons and Cultures of Oceanic Speakers}

In the period since the break-up of POc perhaps 3,500 years ago, many of the descendants of POc have undergone radical transformations while others have changed much less. The most conservative languages, lexically, have probably been some members of the Meso-Melanesian Cluster, especially Bali-Vitu and the Willaumez chain, all the languages located in the eastern half of the main Solomon Island chain from eastern Santa Isabel and Guadalcanal to Santa Ana, parts of central and northern Vanuatu, all the Fijian languages and some Polynesian languages (especially Tongan). Most of these languages retain reflexes of 35-45 per cent of some 250 Proto-Malayo-Polynesian basic vocabulary items reconstructed by Blust $(1981,1993)$. At the other extreme are languages which retain only a small percentage - in the most extreme cases, fewer than 10 per cent - of the reconstructed etyma. Most languages are somewhere between these extremes. Among Oceanic languages there is a rough — by no means exact 
- correlation between lexical and grammatical conservatism and a much lesser correlation between lexical and phonological conservatism. With a handful of exceptions all the lexically most innovative languages are found in the area of the New Guinea mainland and New Britain.

Linguists have for several generations been vexed by these highly innovative (sometimes called "aberrant") languages. Among the explanations that have been offered to account for their high degree of vocabulary replacement are: (i) imperfect acquisition of an Oceanic language by a non-Austronesian (Papuan) speech community, (ii) long-term bilingualism between Oceanic and Papuan neighbours, sustained by trade and intermarriage, (iii) very small size of speech communities, as the result of migration, political structures, etc., (iv) social pressures to develop a distinct language from one's neighbours, (v) taboos on using words coinciding with the names of chiefs or of the dead, (vi) changes of physical environment following migration, (vii) cultural changes generated internally, (viii) cultural changes generated by contact, and (ix) phonological change creating problematic (especially ambiguous) word forms.

By far the most controversial of these proposals, because it conflicts with the hypothesis of founder settlement, is (i), the so-called "pidginization" hypothesis, elaborated by Ray (1926) and Capell (1943). The current consensus is that few, if any, Oceanic languages show evidence of the imperfect learning and heavy substrate residue which would indicate their takeover by a community whose previous language was Papuan. To explain most cases we need to look to a combination of the other factors.

In parts of Melanesia at least as far east as the central Solomons there has been sustained interaction between Oceanic and Papuan language communities, associated with trade and intermarriage. The resultant bilingualism has in a number of cases caused a radical restructuring, especially in grammar, of Oceanic languages. Lynch (1981) argues that the subject-object-verb order and postpositions of the Papuan Tip group are attributable to Papuan influence on Proto-Papuan Tip. One Papuan Tip language, Maisin, has undergone so much Papuanization that earlier commentators could not decide whether it was Papuan or Austronesian (Ross forthcoming). Dutton (1982) has analysed the borrowing and reborrowing of vocabulary in Magori, also a Papuan Tip language. The Bel languages of the North New Guinea group show significant Papuanization in their grammatical structures (Ross 1987, forthcoming), and Lincoln (1976) describes the contrast between Papuanized Piva and un-Papuanized Banoni, two otherwise closely related languages of Bougainville. However, while such sustained language contact and bilingualism has certainly promoted linguistic change, it seems rarely to have led to the adoption of Austronesian languages by Papuan speakers which Ray and Capell argued for. Where the latter did 
occur, it probably wrought changes in phonology rather than grammatical structure (Ross 1994a).

It should surprise no-one that a change of physical or cultural environment led some Oceanic language communities to lose many POc words and change the meanings of others. Sometimes it is possible to work out the approximate period in the history of these languages when the terms in question were lost. For example, although New Zealand Maori no longer has terms for a great many plants and animals of the Pacific tropical environment (Biggs 1994), we can be sure that such terms were present in the immediate common ancestor of Maori, Rarotongan, Tahitian and Tuamotuan, because the latter retain Proto-Polynesian terms for many such items, and we can infer that the losses occurred only after Maori separated from these other languages. In the same way, even though in the central Pacific the megapode or brush turkey is now found only on one remote island (Niuafo'ou, between Tonga and Samoa), we know that speakers of Proto-Polynesian retained the POc (and Proto-Eastern Malayo-Polynesian) word for the megapode and that the term was lost in daughter languages only after the break-up of Proto-Polynesian. This inference can be made because the Niuafo' ou language (a Polynesian language spoken on Niuafo' ou Island between Tonga and Samoa) retains the POc term, ${ }^{*}$ malau. It is supported by the recent discovery of megapode bones in archaeological sites in Fiji. In certain Oceanic languages spoken inland on large islands in Melanesia the loss of terms for the maritime environment can be shown to be fairly recent, because the languages in question are closely related to coastal languages which retain many POc maritime-related terms.

\section{Conclusions}

It remains to sum up the implications of the linguistic evidence reviewed here for reconstructing the prehistory of the Pacific.

1. The distribution of subgroups suggests that POc developed as a distinctive speech tradition following a movement of Eastern Malayo-Polynesian speakers from the Bird's Head of New Guinea to a region further east in northwest Melanesia. It is possible that the movement was in the first instance to the Sarmi Coast and/or the Jayapura regions immediately east of the Bird's Head. However, the most probable dispersal point for all Oceanic subgroups east of Irian Jaya is in the Bismarck Archipelago, where several high-order subgroups are contiguous.

2. After a period of unified development (probably not more than a few centuries) in northwest Melanesia POc speakers spread rapidly over most of Island Melanesia and into West Polynesia and Micronesia. If we accept the connection between the fairly well-dated spread of Lapita culture and the spread of Oceanic, the initial dispersal across Island Melanesia took 
place in the second half of the second millennium BC. At about the same time, Oceanic speakers may have begun to settle on islands close to the New Guinea mainland around the Huon Peninsula. Settlement of the north coast of the mainland and the Huon Gulf may have been somewhat later. Following settlement of the Southeast Papuan region, speakers of a Papuan Tip language moved westwards along the south coast of Papua. This last movement can be correlated with the appearance of a pottery-bearing culture in the Central Province around 2000 years ago.

3. Partial reconstruction of various POc terminologies denoting domains and categories of social structure and material culture is possible. These reconstructions show, very clearly, that POc speakers preserved fairly completely the Proto-Malayo-Polynesian and Proto-Eastern Malayo-Polynesian terminologies for many cultural domains, e.g. the canoe complex, marine life and fishing techniques, cultivated plants, and kinship. At least five Proto-Malayo-Polynesian pottery terms ${ }^{19}$ were retained. However, POc speakers evidently did not preserve terms for rice culture.

4. Some Oceanic communities have retained much more of the total POc lexicon than others. If we measure cultural conservatism in terms of the degree of retention of terminologies for various specific domains of technology and social structure, there is (not surprisingly) a fairly high correlation between linguistic and cultural conservatism.

\section{References}

Allen, Jim

1977a Fishing for wallabies: trade as a mechanism of social interaction, integration and elaboration on the Central Papuan coast. In J. Friedman and M.J. Rowlands (eds) The evolution of social systems, pp.419-455. London: Duckworth.

1977b Management of resources in prehistoric coastal Papua. In John H. Winslow (ed.) The Melanesian environment, pp.35-44. Canberra: Australian National University Press.

Bellwood, Peter S.

1989 The colonization of the Pacific: some current hypotheses. In A. V. S. Hill and S. W. Serjeantson (eds) The colonization of the Pacific: a genetic trail, pp.11-59. Oxford: Clarendon Press.

Bender, Byron W.

1971 Micronesian languages. In Thomas A. Sebeok (ed.) Current trends in linguistics 8: Linguistics in Oceania, pp.426-465. The Hague: Mouton.

Bender, Byron W. and Judith W. Wang 
1985 The status of Proto-Micronesian. In Andrew K. Pawley and Lois Carrington (eds) Austronesian linguistics at the 15th Pacific science congress, pp.53-92. Pacific Linguistics Series C No. 88. Canberra: Department of Linguistics, Research School of Pacific Studies, The Australian National University.

Biggs, Bruce G.

1965 Direct and indirect inheritance in Rotuman. Lingua 14:383-415.

1971 The languages of Polynesia. In Thomas A. Sebeok (ed.) Current trends in linguistics 8: Linguistics in Oceania, pp.466-505. The Hague: Mouton.

1980 The position of East 'Uvean and Anutan in the Polynesian language family. Te Reo 22-23:115-134.

1994 New words for a new world. In Andrew Pawley and Malcolm D. Ross (eds) Austronesian terminologies: continuity and change. Pacific Linguistics Series C No. 127, pp.21-29. Canberra: Department of Linguistics, Research School of Pacific and Asian Studies, The Australian National University.

Blust, Robert A.

1978a Eastern Malayo-Polynesian: a subgrouping argument. In S.A. Wurm and Lois Carrington (eds) Second international conference on Austronesian linguistics: proceedings, pp.181-234. Pacific Linguistics Series C No. 61. Canberra: Department of Linguistics, Research School of Pacific Studies, The Australian National University.

1978b The Proto-Oceanic palatals. Journal of the Polynesian Society Monograph 43. Auckland: The Polynesian Society.

1981 Variation in retention rate among Austronesian languages. Paper presented to the Third International Conference on Austronesian Linguistics, Denpasar.

1982 The linguistic value of the Wallace line. Bijdragen tot de Taal-, Land-en Volkenkunde 138:231-250.

1983-84 More on the position of the languages of Eastern Indonesia. Oceanic Linguistics 22-23:1-28.

1993 Central and Central-Eastern Malayo-Polynesian. Oceanic Linguistics 32: 241-293.

Bulmer, Susan

1982 West of Bootless Inlet: archaeological evidence for prehistoric trade in the Port Moresby area and the origins of the hiri. In T.E. Dutton (ed.) The hiri in history: further aspects of long-distance Motu trade in central Papua, pp.117-130. Pacific Research Monograph No. 8. Canberra: The Australian National University. 
Capell, Arthur

1943 The linguistic position of South-Eastern Papua. Sydney: Australasian Medical Publishing Company.

Chowning, Ann

1963 Proto-Melanesian plant names. In Jacques Barrau (ed.) Plants and the migrations of Pacific peoples: a symposium, pp.39-44. Honolulu: Bishop Museum Press.

1989 The 'Papuan Tip' languages reconsidered. In Ray Harlow and Robin Hooper (eds) VICAL 1: Oceanic languages. Papers from the fifth international conference on Austronesian linguistics, pp.113-140. Auckland: Linguistic Society of New Zealand.

1991 Proto Oceanic culture: the evidence from Melanesia. In Robert Blust (ed.) Currents in Pacific linguistics: papers on Austronesian languages and ethnolinguistics in honour of George W. Grace, pp.43-75. Pacific Linguistics Series C No. 117. Canberra: Department of Linguistics, Research School of Pacific Studies, The Australian National University.

Clark, Ross

1982 Proto-Polynesian birds. In Jukka Siikala (ed.) Oceanic studies: essays in honour of Aarne A. Koskinen, pp.121-143. Helsinki: Suomen Antropologinen Seura/The Finnish Anthropological Society.

1985 Languages of north and central Vanuatu: groups, chains, clusters and waves. In Andrew Pawley and Lois Carrington (eds) Austronesian linguistics at the 15th Pacific science congress, pp.199-236. Pacific Linguistics Series C No. 88. Canberra: Department of Linguistics, Research School of Pacific Studies, The Australian National University.

1991 Fingota/Fangota: shellfish and fishing in Polynesia. In Andrew Pawley (ed.) Man and a half: essays in Pacific anthropology and ethnobiology in honour of Ralph Bulmer, pp.78-83. Auckland: The Polynesian Society.

1994 The word is the bird: evolution, migration and extinction of Oceanic ornithonyms. In Andrew Pawley and Malcolm D. Ross (eds) Austronesian terminologies: continuity and change. Pacific Linguistics Series C No. 127, pp.73-86. Canberra: Department of Linguistics, Research School of Pacific and Asian Studies, The Australian National University.

Dempwolff, Otto

1934 Vergleichende Lautlehre des Austronesischen Wortschatzes, Band 1: Induktiver Aufbau einer indonesischen Ursprache. Beihefte zur Zeitschrift für Eingeborenen-Sprachen 15. Berlin: Dietrich Reimer. 
1937 Vergleichende Lautlehre des Austronesischen Wortschatzes, Band 2: Deduktive Anwendung des Urindonesischen auf Austronesische Einzelsprachen. Beihefte zur Zeitschrift für Eingeborenen-Sprachen 17. Berlin: Dietrich Reimer.

1938 Vergleichende Lautlehre des Austronesischen Wortschatzes, Band 3: Austronesisches Wörterverzeichnis. Beihefte zur Zeitschrift für EingeborenenSprachen 19. Berlin: Dietrich Reimer.

Dutton, T.E.

1982 Borrowing in Austronesian and non-Austronesian languages of coastal south-east mainland Papua New Guinea. In Amran Halim, Lois Carrington and S.A. Wurm (eds) Papers from the third international conference on Austronesian linguistics 1: Currents in Oceanic, pp.109-177. Pacific Linguistics Series C No. 74. Canberra: Department of Linguistics, Research School of Pacific Studies, The Australian National University.

Dutton, Tom and Darrell Tryon (eds)

1994 Language contact and change in the Austronesian world. Berlin: Mouton de Gruyter.

Dyen, Isidore

1956 Language distribution and migration theory. Language 32:611-626.

1981 The subgrouping of the Polynesian languages. In K.J. Hollyman and Andrew Pawley (eds) Studies in Pacific languages and cultures, in honour of Bruce Biggs, pp.83-100. Auckland: Linguistic Society of New Zealand.

French-Wright, Renwick

1983 Proto-Oceanic horticultural practices. M.A. thesis, Department of Anthropology, University of Auckland.

Geraghty, Paul

1983 The history of the Fijian languages. Oceanic Linguistics special publication No. 19. Honolulu: University of Hawaii Press.

1986 The sound system of Proto-Central-Pacific. In Paul Geraghty, Lois Carrington and S.A. Wurm (eds) FOCAL II: papers from the fourth international conference on Austronesian linguistics, pp.289-312. Pacific Linguistics Series C No. 94. Canberra: Department of Linguistics, Research School of Pacific Studies, The Australian National University.

1989 The reconstruction of Proto-Southern Oceanic. In Ray Harlow and Robin Hooper (eds) VICAL 1: Oceanic languages. Papers from the fifth international conference on Austronesian linguistics, pp.141-156. Auckland:

Linguistic Society of New Zealand. 
1990 Proto-Eastern Oceanic ${ }^{*} R$ and its reflexes. In J.H.C.S. Davidson (ed.) Pacific island languages: essays in honour of G.B. Milner, pp.51-93. London and Honolulu: School of Oriental and African Studies and University of Hawaii Press.

1994 Proto Central Pacific fish-names. In Andrew Pawley and Malcolm D. Ross (eds) Austronesian terminologies: continuity and change. Pacific Linguistics Series C No. 127, pp.141-169. Canberra: Department of Linguistics, Research School of Pacific and Asian Studies, The Australian National University.

Geraghty, Paul and Andrew K. Pawley

1981 The relative chronology of some innovations in the Fijian languages. In Jim Hollyman and Andrew Pawley (eds) Studies in Pacific languages and cultures in honour of Bruce Biggs, pp.159-178. Auckland: Linguistic Society of New Zealand.

Grace, George W.

1959 The position of the Polynesian languages within the Austronesian (MalayoPolynesian) language family. Bloomington: Indiana University Publications in Anthropology and Linguistics, Memoir 16, supplement to International Journal of American Linguistics 25.

1971 Notes on the phonological history of the Austronesian languages of the Sarmi coast. Oceanic Linguistics 10:11-37.

Green, Roger C.

1963 A suggested revision of the Fijian sequence. Journal of the Polynesian Society 72:235-252.

1981 Location of the Polynesian homeland: a continuing problem. In Jim Hollyman and Andrew Pawley (eds) Studies in Pacific languages and cultures in honour of Bruce Biggs, pp.133-158. Auckland: Linguistic Society of New Zealand.

1994 Changes over time: recent advances in dating human colonisation of the Pacific area. In D.G. Sutton (ed.) Origins of the first New Zealanders, pp.19-51. Auckland: Auckland University Press.

Hooper, Robin

1985 Proto-Oceanic /*qi/. In Andrew K. Pawley and Lois Carrington (eds) Austronesian linguistics at the 15th Pacific science congress, pp.141-167. Pacific Linguistics Series C No. 88. Canberra: Department of Linguistics, Research School of Pacific Studies, The Australian National University.

1994 Proto-Polynesian fish names. In Andrew Pawley and Malcolm D. Ross (eds) Austronesian terminologies: continuity and change. Pacific Linguistics 
Series C No. 127, pp.185-229. Canberra: Department of Linguistics, Research School of Pacific and Asian Studies, The Australian National University.

Jackson, Frederick H.

1983 The internal and external relationships of the Trukic languages of Micronesia. Honolulu: University of Hawaii.

Kern, Hendrik

1886 De Fidji-taal vergeleken net hare verwanten in Indonesië en Polynesië. Verhandelingen der Koninklijke Akademie van Wetenschappen, afdeeling Letterkunde 16:1-242.

Kirch, Patrick V.

1984 The evolution of the Polynesian chiefdoms. Cambridge: Cambridge University Press.

1992 The Lapita culture of western Melanesia in the context of Austronesian origins and dispersals. Paper presented to the International Symposium on Austronesian Studies relating to Taiwan, Academia Sinica, Nankang, Taipei.

Kirch, Patrick V. and T.L. Hunt (eds)

1988 Archaeology of the Lapita cultural complex: a critical review. Thomas Burke Memorial Washington State Museum Monograph 5. Seattle: Burke Museum.

Levy, Richard S.

1979 The phonological history of the Bugotu-Nggelic languages and its implications for Eastern Oceanic. Oceanic Linguistics 18:1-31.

1980 Languages of the southeast Solomon Islands and the reconstruction of Proto-Eastern-Oceanic. In Paz Buenaventura Naylor (ed.) Austronesian studies: papers from the second eastern conference on Austronesian languages, pp.213-222. Ann Arbor: University of Michigan, Center for South and Southeast Asian Studies.

Lichtenberk, Frantisek

1986 Leadership in Proto Oceanic society: linguistic evidence. Journal of the Polynesian Society 95:341-356.

1988 The Cristobal-Malaitan subgroup of Southeast Solomonic. Oceanic Linguistics 27:24-62.

1994 The raw and the cooked: Proto-Oceanic terms for food preparation. In Andrew Pawley and Malcolm D. Ross (eds) Austronesian terminologies: continuity and change. Pacific Linguistics Series C No. 127, pp.267-288. 
The Austronesians: Historical and Comparative Perspectives

Canberra: Department of Linguistics, Research School of Pacific and Asian Studies, The Australian National University.

Lilley, Ian

1988 Prehistoric exchange across the Vitiaz Strait, Papua New Guinea. Current Anthropology 29:513-516.

1990 Final report: Prehistoric settlement and trade in northwest New Britain, Papua New Guinea. Typescript. University of Western Australia.

Lincoln, Peter C.

1976 Banoni, Piva and Papuanization. In Ger P. Reesink, Lillian Fleischmann, Sinikka Turpeinen and Peter C. Lincoln (eds) Papers in New Guinea linguistics No. 19, pp.77-105. Pacific Linguistics Series A No. 45. Canberra: Department of Linguistics, Research School of Pacific Studies, The Australian National University.

Lynch, John

1978 Proto-South Hebridean and Proto-Oceanic. In S.A. Wurm and Lois Carrington (eds) Second international conference on Austronesian linguistics: proceedings, pp.717-779. Pacific Linguistics Series C No. 61. Canberra: Department of Linguistics, Research School of Pacific Studies, The Australian National University.

1981 Melanesian diversity and Polynesian homogeneity: the other side of the coin. Oceanic Linguistics 20:95-129.

Lynch, John and D.T. Tryon

1985 Central-Eastern Oceanic: a subgrouping hypothesis. In Andrew K. Pawley and Lois Carrington (eds) Austronesian linguistics at the 15th Pacific science congress, pp.31-52. Pacific Linguistics Series C No. 88. Canberra: Department of Linguistics, Research School of Pacific Studies, The Australian National University.

Marck, Jeffrey C.

1986 Micronesian dialects and the overnight voyage. Journal of the Polynesian Society 95:253-258.

1994 Proto-Micronesian terms for the physical environment. In Andrew Pawley and Malcolm D. Ross (eds) Austronesian terminologies: continuity and change. Pacific Linguistics Series C No. 127, pp.301-328. Canberra: Department of Linguistics, Research School of Pacific and Asian Studies, The Australian National University.

Milke, Wilhelm 
1938 Die Benennungen der Geschwister in den austronesischen Sprachen Ozeaniens. Zeitschrift für Eingeborenen-Sprachen 70:51-66.

1958 Zur inneren Gliederung und geschtichtlichen Stellung der ozeanischAustronesischen Sprachen. Zeitschrift für Ethnologie 83:58-62.

1961 Beiträge zur ozeanischen Linguistik. Zeitschrift für Ethnologie 86:162182.

Osmond, Meredith

1993 Proto Oceanic terms for fishing and hunting implements. Paper presented to the First International Conference on Oceanic Linguistics, Vila, Vanuatu.

Pawley, Andrew K.

1966 Polynesian languages: a subgrouping based on shared innovations in morphology. Journal of the Polynesian Society 75:39-64.

1967 The relationships of Polynesian Outlier languages. Journal of the Polynesian Society 76:259-296.

1972 On the internal relationships of eastern Oceanic languages. In R.C. Green and M. Kelly (eds) Studies in Oceanic culture history, vol. 3, pp.1-142. Honolulu: Bernice Pauahi Bishop Museum.

1975 The relationships of the Austronesian languages of Central Papua. In T.E. Dutton (ed.) Studies in languages of Central and South-East Papua, pp.3-106. Pacific Linguistics Series C No. 29. Canberra: Department of Linguistics, Research School of Pacific Studies, The Australian National University.

1977 On redefining 'Eastern Oceanic'. Mimeo.

1979 New evidence on the position of Rotuman. Working Papers in Anthropology, Archaeology, Linguistics and Maori Studies 56. Department of Anthropology, University of Auckland.

1981 Melanesian diversity and Polynesian homogeneity: a unified explanation for language. In Jim Hollyman and Andrew Pawley (eds) Studies in Pacific languages and cultures in honour of Bruce Biggs, pp.269-309. Auckland: Linguistic Society of New Zealand.

1982 Rubbish-man commoner, big man chief? Linguistic evidence for hereditary chieftainship in Proto-Oceanic society. In Jukka Siikala (ed.) Oceanic studies: essays in honour of Aarne A. Koskinen, pp.33-52. Transactions of the Finnish Anthropological Society 11. Helsinki: Suomen Antropologinen Seura/The Finnish Anthropological Society. 
1993 Proto Oceanic terms for reef and shoreline invertebrates. Paper presented to the First International Conference on Oceanic Linguistics, Vila, Vanuatu.

Pawley, Andrew and Kaye Green

1971 Lexical evidence for the Proto-Polynesian homeland. Te Reo 14:1-35.

Pawley, Andrew K. and Roger C. Green

1984 The Proto-Oceanic language community. Journal of Pacific History 19:123146.

Pawley, Andrew K. and Medina Pawley

1994 Early Austronesian terms for canoe parts and seafaring. In Andrew Pawley and Malcolm D. Ross (eds) Austronesian terminologies: continuity and change. Pacific Linguistics Series C No.127, pp.329-361. Canberra: Department of Linguistics, Research School of Pacific and Asian Studies, The Australian National University.

Pawley, Andrew K. and Malcolm D. Ross

1993 Austronesian historical linguistics and culture history. Annual Review of Anthropology 22:425-459.

Pawley, Andrew and Timoci Sayaba

1971 Fijian dialect divisions: Eastern and Western Fijian. Journal of the Polynesian Society 80:405-436.

Ray, Sidney H.

1926 A comparative study of the Melanesian island languages. Cambridge: Cambridge University Press.

Rensch, Karl

1987 East Uvean, Nuclear Polynesian? Reflections on the methodological adequacy of the tree model in Polynesia. In Donald C. Laycock and Werner Winter (eds) A world of language: papers presented to Professor S.A. Wurm on his 65th birthday, pp.565-581. Pacific Linguistics Series C No. 100. Canberra: Department of Linguistics, Research School of Pacific Studies, The Australian National University.

Ross, Malcolm D.

1987 A contact-induced morphosyntactic change in the Bel languages of Papua New Guinea. In Donald C. Laycock and Werner Winter (eds) $A$ world of language: papers presented to Professor S.A. Wurm on his 65th birthday, pp.583-601. Pacific Linguistics Series C No. 100. Canberra: Department of Linguistics, Research School of Pacific Studies, The Australian National University. 
1988 Proto Oceanic and the Austronesian languages of western Melanesia. Pacific Linguistics Series C No. 98. Canberra: Department of Linguistics, Research School of Pacific Studies, The Australian National University.

1989 Early Oceanic linguistic prehistory: a reassessment. Journal of Pacific History 24:135-149.

1992 The position of Gumawana among the languages of the Papuan Tip cluster. Language and Linguistics in Melanesia 23:139-165.

1993 *kanay ma wasa: reconstructing food plant terms and associated terminologies in Proto Oceanic. Paper presented to the First International Conference on Oceanic Linguistics, Port Vila, Vanuatu.

1994a Areal phonological features in north central New Ireland. In Tom Dutton and Darrell Tryon (eds) Language contact and change in the Austronesian world, pp.551-572. Berlin: Mouton de Gruyter.

1994b Central Papuan culture history: some lexical evidence. In Andrew Pawley and Malcolm D. Ross (eds) Austronesian terminologies: continuity and change. Pacific Linguistics Series C No. 127, pp.389-479. Canberra: Department of Linguistics, Research School of Pacific and Asian Studies, The Australian National University.

1994c Pottery terms in Proto Oceanic. Typescript. The Australian National University, Canberra.

1994d Proto Oceanic terms for meteorological phenomena. Paper presented to the Seventh International Conference on Austronesian Linguistics, Leiden.

Forth-coming Contact-induced change and the comparative method: cases from Papua New Guinea. In Mark Durie and Malcolm D. Ross (eds) The comparative method reviewed: irregularity and regularity in linguistic change. New York: Oxford University Press.

Sapir, Edward

1916 Time perspective in aboriginal American culture. Memoir 90, Anthropological series 13. Ottawa: Geological Survey, Department of Mines. Reprinted in David T. Mandelbaum (ed. 1949) Selected writings of Edward Sapir in language, culture and personality, pp.389-462. Berkeley: University of California Press.

Shutler, Richard and Jeffrey C. Marck

1975 On the dispersal of the Austronesian horticulturalists. Archaeology and Physical Anthropology in Oceania 10:81-113.

Spriggs, Matthew J.T.

1984 The Lapita cultural complex. Journal of Pacific History 19:202-223. 
1989 The dating of the Island Southeast Asian Neolithic: an attempt at chronometric hygiene and linguistic correlation. Antiquity 63:587-612.

1990 Dating Lapita: another view. In M. Spriggs (ed.) Lapita design, form and composition, pp.6-27. Canberra: Department of Prehistory, Research School of Pacific Studies, The Australian National University.

1993 Island Melanesia: the last 10,000 years. In M. Spriggs, D. Yen, W. Ambrose, R. Jones, A. Thorne and A. Andrews (eds) Community of culture: the people and prehistory of the Pacific, pp.187-205. Canberra: Australian National University Press.

Thurston, William R.

1987 Processes of change in the languages of north-western New Britain. Pacific Linguistics Series B No. 99. Canberra: Department of Linguistics, Research School of Pacific Studies, The Australian National University.

Tryon, D.T.

1976 New Hebrides languages: an internal classification. Pacific Linguistics Series C No. 50. Canberra: Department of Linguistics, Research School of Pacific Studies, The Australian National University.

Tryon, D.T. and B.D. Hackman

1983 Solomon Islands languages: an internal classification. Pacific Linguistics Series C No. 72. Canberra: Department of Linguistics, Research School of Pacific Studies, The Australian National University.

Vanderwal, R.

1973 Prehistoric studies in central coastal Papua. PhD dissertation, The Australian National University, Canberra.

Walter, Richard

1989 Lapita fishing strategies: a review of the archaeological and linguistic evidence. Journal of Pacific Studies 31:127-149.

Wurm, S.A.

1967 Linguistics and the prehistory of the south-western Pacific. Journal of Pacific History 2:25-38.

\section{Notes}

${ }^{1}$ We are indebted to Peter Bellwood for useful comments on the original draft of this paper. The revised version takes account of relevant developments in the field in 1991-93.

2 The "classical" comparative method was codified by a German linguistic school, the Neogrammarians, who flourished in the last third of the nineteenth century, building on a large body of work in Indo-European comparative linguistics developed by nineteenth-century scholars.

3 An asterisk marks reconstructed form. 
4 Another method used to subgroup languages is lexicostatistics, popularized by Morris Swadesh and others in the 1950s. Lists of words for the same set of meanings are collected from a number of languages, and for every pair of languages each pair of words is marked as either "cognate" or "non-cognate"; the percentage of the items in the list which are deemed cognate for each pair of languages is calculated. This "cognate percentage" is then taken to be a measure of the genetic relationship of the two languages. The fundamental fault of lexicostatistics is its assumption, rejected by most comparative linguists, that over long periods of time all languages replace their vocabulary at approximately the same rate. Blust (1981) is a major study of Austronesian evidence which shows great variation among languages in their replacement rates. In addition, lexicostatistics is unable to take proper account of the effects of borrowing.

5 Glottochronology, an outgrowth of lexicostatistics, at best provides very rough indicators because of differing rates of change among languages.

${ }^{6}$ For references to research on Proto-Oceanic since Dempwolff (1934-38), see Blust (1978b), Ross (1988), and Pawley and Ross (1993).

7 Examples of POc terminologies are French-Wright (1983) and Ross (1993) on horticulture and food plants; Chowning (1963) on plants; Walter (1989) on fishing; Osmond (1993) on fishing and hunting implements, Pawley (1993) on reef creatures, Clark (1994) on birds; Lichtenberk (1994) on cookery; Pawley and Pawley (1994) on canoes and canoe parts; Ross (1994c) on pottery; Ross (1994d) on meteorological terms; Milke $(1938,1958)$ on kinship; and the debate on the nature of leadership in POc society (Pawley 1982; Lichtenberk 1986), whilst Chowning (1991) offers a survey of POc culture. There are also works on terminologies in interstage languages. These include Geraghty (1994) on Proto-Central Pacific fish; Marck (1994) on the Proto-Nuclear Micronesian physical environment; and a variety of Proto-Polynesian terminologies in kinship and society (Pawley 1982) and other domains (Pawley and K. Green 1971; Clark 1982, 1991; Hooper 1985, 1994). POc lexical reconstructions scattered across various sources probably total close to 2000 .

8 Ross (1988:8) used the terms "family" and "linkage" (with "chain" and "network" as particular configurations of linkage) for an innovation-defined and an innovation-linked subgroup respectively. Because these terms also have other connotations for linguists, we have replaced them by the more transparent, if albeit clumsier, terms here.

9 The two kinds of innovation pattern have been appreciated almost since the beginnings of the comparative method, and resulted in the "family tree" and "wave" models. The latter was intended, however, to reflect the great European dialect networks of English, Dutch/German, or Western Romance, rather than language linkages like those of, say, the Milne Bay Province of Papua New Guinea.

10 The modes of subgroup formation that result in innovation-defined and innovation-linked subgroups have been described more fully by Pawley and Green (1984) under the labels "radiation" and "network-breaking" and by Ross (1988:7-11) under "separation" and "dialect differentiation".

11 Omitted from this grouping due to lack of evidence or the absence of studies are (i) the Oceanic languages of Irian Jaya; (ii) Yapese; (iii) the languages of Utupua and Vanikoro in the Te Motu Province of the Solomon Islands.

12 Readers familiar with the literature on Oceanic languages may be puzzled by the absence of an "Eastern Oceanic" subgroup from our listing of high-order groups. Several attempts have been made to show the existence of such a subgroup including some or all of groups 4 to 9, but none has been convincing. It has proven difficult to establish an innovation-linked subgroup on this scale, let alone an innovation-defined one. References to various "Eastern Oceanic" hypotheses include Pawley (1972, 1977), Lynch and Tryon (1985; cf. Ross 1988:393), and Geraghty (1990).

13 Clark (1985:219-220) has also presented innovations which link South Vanuatu to North/Central Vanuatu.

14 Belau and Chamorro are both non-Oceanic Austronesian languages whose closest relatives are probably to be found in the Philippines. Yapese is an Austronesian language whose position in the family has yet to be clearly established.

15 Chowning (1989) has recently questioned the integrity of the Papuan Tip group. Her arguments are discussed by Ross (1992). If they were accepted, they would result only in the exclusion from the group of the Kilivila family, i.e. three of the 54 languages attributed to the group by Ross (1988).

16 The Jayapura and Sarmi Coast (Grace 1971) subgroups may also be part of the North New Guinea grouping, but the available data are insufficient for us to be certain.

17 Ross (1988) has argued that if POc was located in the New Britain region, then two waves of eastward migration may have originated there: the first was ancestral to all Oceanic subgroups other than Western Oceanic, the second resulted in the Meso-Melanesian group. Under this scenario, Meso-Melanesian 
probably displaced first-wave languages on New Ireland and in the northwest Solomons, providing an explanation of the quite sharp differences between Meso-Melanesian languages and their neighbours in the St Matthias group to the north and the Southeast Solomonic group to the southeast. This entails the possibility that the Meso-Melanesian speakers of the second wave were more "Papuanized" than the pre-Eastern Oceanic speakers of the first wave, and were thereby better equipped to settle the Meso-Melanesian region, which was already occupied by Papuan speakers.

18 These thoughts are not new: see Green (1963) and Wurm (1967).

19 POc *kuron 'pot', "pala $y$ a 'frying pan', *b ${ }^{w}$ ay a 'k.o. large pot', * $r a R o(q)$ 'clay' and *tapi 'paddle for beating clay into shape'. 